\title{
Achieving Energy Efficient Ship Operations Under Third Party Management How Do Ship Management Models Influence Energy Efficiency?
}

Taudal Poulsen, René; Sornn-Friese, Henrik

Document Version

Accepted author manuscript

Published in:

Research in Transportation Business \& Management

DOI:

10.1016/j.rtbm.2015.10.001

Publication date:

2015

License

Unspecified

Citation for published version (APA):

Taudal Poulsen, R., \& Sornn-Friese, H. (2015). Achieving Energy Efficient Ship Operations Under Third Party Management: How Do Ship Management Models Influence Energy Efficiency? Research in Transportation Business \& Management, 17, 41-52. https://doi.org/10.1016/j.rtbm.2015.10.001

Link to publication in CBS Research Portal

\section{General rights}

Copyright and moral rights for the publications made accessible in the public portal are retained by the authors and/or other copyright owners and it is a condition of accessing publications that users recognise and abide by the legal requirements associated with these rights.

\section{Take down policy}

If you believe that this document breaches copyright please contact us (research.lib@cbs.dk) providing details, and we will remove access to the work immediately and investigate your claim. 


\title{
Achieving Energy Efficient Ship Operations Under Third Party Management: How Do Ship Management Models Influence Energy Efficiency?
}

\author{
René Taudal Poulsen and Henrik Sornn-Friese \\ Journal article (Post print version)
}
This article was originally published in Research in Transportation Business \& Management

First published online: 23 October 2015.

DOI: $\underline{10.1016 / j . r t b m .2015 .10 .001}$

Uploaded to Research@CBS: September 2015

Available at: http://research.cbs.dk/da/publications/uuid\%284c0283aa-3ecd4d28-94f2-3a961bde89f4\%29.html

(C) 2015. This manuscript version is made available under the CC-BY-NC-ND 4.0 license http://creativecommons.org/licenses/by-nc-nd/4.0/ 


\title{
Achieving energy efficient ship operations under third party management:
}

\section{How do ship management models influence energy efficiency?}

\begin{abstract}
Profitable energy saving measures are often not fully implemented in shipping, causing energy efficiency gaps. The paper identifies energy efficiency gaps in ship operations, and explores their causes. Lack of information on energy efficiency, lack of energy training at sea and onshore and lack of time to produce and provide reliable energy efficiency information cause energy efficiency gaps. The paper brings together the energy efficiency and ship management literatures, demonstrating how ship management models influence energy efficiency in ship operations. Achieving energy efficiency in ship operations is particularly challenging under third party ship management. Finally, the paper discusses management implications for shipping companies, which outsource ship management to third parties.
\end{abstract}

\section{Highlights}

We bring the energy efficiency and ship management literatures together

Energy efficiency gaps exist in ship operations

Lack of information, training and time cause energy efficiency gaps

Ship management models influence energy efficiency

Trade-off between outsourcing of crewing and energy efficiency 


\section{Keywords}

Energy efficiency gaps; Energy efficiency barriers; Imperfect information; Ship management;

\section{Introduction}

Scholars have for a long time debated the extent to which energy efficiency gaps occur (Jaffe, Stavins 1994), as well as what causes such gaps (Allcott, Greenstone 2012, Bunse et al. 2011, Thollander, Palm 2012, Sivill et al. 2013, Jaffe, Stavins 1994). Indeed, a rich body of literature has evolved, identifying barriers to energy efficiency (Trianni, Cagno 2012). Barriers, in this literature are all the factors that impede the adoption of cost effective, energy efficient technologies and practices or delay their diffusion (Fleiter, Worrell \& Eichhammer 2011). The issue of achieving energy efficiency has received considerable attention from practitioners in the shipping industry. International shipping is highly energy intensive, with energy costs constituting up to $65 \%$ of voyage costs in 2012-13 (Lloyd's List 2012, Lloyd's List 2013a, Lloyd's List 2014a). Indeed, fuel efficiency came top of the list in a landmark survey carried out by the corporate law firm Norton Rose in 2013 (Lloyd's List 2013b).

Several recent studies have argued that a cost effective potential for fuel saving exists in shipping. (Buhaug et al. (2009), Eide et al. (2009), Eide et al. (2011a), and Faber, Behrends \& Nelissen (2011) discussed various measures to reduce shipping's fuel consumption and argued that a wide range of options for increasing energy efficiency and reducing emissions by changing ship design and ship operation has been identified, but also that a considerable proportion of the potential abatement appears to be cost effective at present. Eide et al. (2011b) followed along the same lines in calculating an average Marginal Abatement Cost Curve for shipping to assess the costs of averting the emission of one ton of $\mathrm{CO} 2$ (which effectively means fuel saving). In addition, they identified several operational measures that could be implemented at net negative costs, including voyage execution, speed reduction, engine monitoring, trim optimization, and weather routing. These day-to-day measures directly concern ship operations, and require little or no 
investments. Faber et al. (2011) also identified several operational measures with fuel saving potential, and Crist (2012) summarized estimates of fuel saving potential in ship operations, which included such measures as reductions in port turn-around time, optimized voyage planning, trim optimization, autopilot optimization, and overall energy awareness in shipping organizations. All these studies indicate that the ship operation decisions made at sea and ashore on a daily basis can influence fuel consumption and cause energy efficiency gaps.

In this paper we are generally concerned with understanding the challenges of energy efficiency in shipping, and specifically concerned with addressing energy efficiency gaps in the context of different ship management models, i.e., whether shipping companies choose to either perform the tasks related to ship operation in-house or outsource them to independent companies. Regarding the latter, we follow the recent call of Johnson, Johansson \& Andersson (2014), who specifically emphasized the need to study energy efficiency in shipping in the context of contract monitoring with respect to third parties.

\subsection{Identifying barriers to energy efficiency}

The United Nation's Intergovernmental Panel on Climate Change (IPCC) has identified four broad classes of barriers to energy efficiency, including lack of information, limited availability of capital, lack of skilled personnel, and other barriers (IPCC 2011). A further attempt of classification was made by Sorrell et al. (2000), Sorrell et al. (2004), and Sorrell, Mallett \& Nye (2011), who offered an economics based taxonomy, developed on the basis of categories that were widely highlighted in the energy efficiency literature, and founded on theoretical concepts and ideas from economics, behavioral perspectives, and organization theory. Specifically, they called attention to six major classes of barriers. First, perceived risk of energy saving investments owing, for example, to fluctuations in energy prices, may prevent firms from adopting energy saving measures, even if these would prove profitable in the longer term (see also Velthuijsen (1993)). Thus, risk aversion may be seen as a major barrier to energy efficiency. 
Second, investment decisions are subject to imperfect information, which may explain why some costeffective opportunities are being missed or why, in some cases, less efficient solutions may drive more efficient solutions out of the market. Indeed, Howarth, Andersson (1993) demonstrated theoretically how problems of imperfect information and transaction costs may bias rational decision-makers to invest in less energy saving measures than those that would be chosen by an informed social planner guided by the criterion of economic efficiency.

Third, there may be substantial hidden costs associated with investments in energy efficiency, such as, overhead costs for management, disruptions to production, staff replacement and training, or costs associated with collecting, analyzing and applying information.

Fourth, limited access to capital may prevent energy efficiency measures from being implemented, as decision-makers choose to pursue other more promising investment opportunities. A survey-based case study of barriers and drivers for energy efficiency in the Swedish foundry industry, for example, found that limited access to capital constitutes by far the largest barrier to energy efficiency closely followed by the risk of hidden costs, and especially the risk of production disruptions (Rohdin, Thollander \& Solding 2007). Fifth, there may be split incentives, or principal-agent problems, in which case energy efficiency opportunities are missed if the decision-maker cannot appropriate the benefits of the investment (Thollander, Palm 2012, Vernon, Meier 2012). Principal-agent problems may occur when two parties enter into a contract and have different goals and levels of information regarding energy saving potential. In the housing sector, for instance, landlords (as agent) may refrain from investments in energy saving measures, because savings would accrue to tenants (as principal), who pay for energy, but do not know about the saving potential. Or to reverse the argument, tenants (in this case with the role of agent) would refrain from energy savings if the landlord pays the energy bills (in this case with the role of the principal), and the landlord cannot monitor the energy consumption of the individual tenants (OECD/IEA 2007). 
Finally, bounded rationality is identified as an important barrier to energy efficiency. Decision-makers are limited by the information available to them, in their cognitive capacities and in the time available to make the decision and, hence, may neglect to pursue energy saving measures, even if they have the appropriate incentives to do so. Rather, decision-makers satisfice, basing their decisions on rule of thumb (Simon, 1957).

Sorrell et al. (2000) included the human dimension as a distinct category to be considered in addition to the categories discussed above, but they emphasized that this dimension is not readily amenable to formal modeling using the standardized tools of optimization theory. Studies of the human dimension have derived mainly from the psychological literature, and they have been framed as more general observations about the process of energy decision rather than as discrete barriers to energy efficiency. In addition, they have included only few empirical studies of energy decisions in organizations. Nevertheless, Sorrell et al. (2000) emphasized three concepts from this literature that could be framed in terms of energy efficiency gaps, including 1) the form in which decision information is presented (i.e., the extent to which it is specific and personalized, vivid, clear and simple, and close in time to the relevant decision, as well as including feedback to previous energy decisions); 2) credibility and trust in information exchange (emphasizing the importance of interpersonal contacts); and 3) inertia (i.e., decision-makers tend to rationalize previous decisions, emphasizing the positive aspects of the decision and the negative aspects of the alternatives that were not chosen).

Sorrell and colleagues organized the identified barriers to energy efficiency according to three theoretical perspectives, as summarized in Table 1. They stressed the conflicting underlying assumptions of those perspectives about the nature of human rationality and the role of market mechanisms, but they also argued for complementarity between them. 
Various methods and frameworks have been applied in studies of energy efficiency in shipping. Johnson, Andersson (2014), Johnson et al. (2013), Johnson (2013) and Johnson, Johansson \& Andersson (2014) applied action research methods. Johnson, Johansson \& Andersson (2014) identified five major barriers to energy efficiency in the shipping companies that they studied: Low level of project management maturity, difficulties measuring energy performance, fragmented responsibilities, lack of communication, and lack of knowledge and resources. Jafarzadeh, Utne (2014) developed a comprehensive framework for ship owners and managers to identify energy efficiency gaps, which included seven broad categories of barriers: Information, economic (such as hidden costs and lack of capital), intra-organizational (such as bounded rationality and inertia), inter-organizational (split incentives), technological (technical risks), policy (conflicting regulation), and geographical (related to shipping in areas with piracy etc.). Rehmatulla, Smith (2013) applied a survey methodology to identify barriers to the implementation of fuel saving initiatives and distinguished between organizational (culture and power), behavioral (bounded rationality, information problems, inertia and trust), and economic barriers (principal-agent problem, asymmetric information, hidden costs etc.) to energy efficiency. In a study of Norwegian shipping, Acciaro, Hoffmann \& Eide (2013) identified barriers for the implementation of cost saving technologies related to principal-agent problems. Finally, Agnolucci, Smith \& Rehmatulla (2014) examined to what extent energy efficiency is remunerated in the panamax, dry bulk time charter market and also found strong evidence that principalagent problems are a main barrier to energy efficiency in shipping.

The above studies have provided valuable insights on important aspects of energy efficiency in shipping, which can be categorized roughly along the same lines as those identified in the general energy efficiency literature discussed above. However, although Shinohara (2005) did discuss the more general concern with quality shipping in the context of third party ship management the specific conditions for energy efficiency in ship operations under different ship management models remain underexplored (see, e.g. Johnson, Johansson \& Andersson (2014)), and we will deal with this issue next. 


\subsection{Ship management models}

According to BIMCO (2009c) about one third of the world fleet operates under third party ship management. Professional ship management companies typically handle crewing and technical management of ships for ship owners based on pre-agreed fees. According to Bjuggren, Palmberg (2009) third party ship management denominates the complete separation of ownership and control in maritime transport and illustrates that labor in shipping (the crew) is not tied to the asset (the vessel) to the same extent as in other industries. Specifically, crewing refers to the employment of the seafarers who operate the ships, while technical management concerns procurement of supplies for vessels as well as the organization of maintenance. In some cases, crewing and technical management are performed by the same third party company, but in other cases the two activities can also be performed by two separate companies. The contract between ship manager and ship owner will specify the nature and extent of the management, which may in certain cases also include commercial management.

Three ship management models have been identified in the ship management literature (Dickie, 2014): The traditional (in-house) ship management model, the outsourcing (third party management) model, and the hybrid model (a combination of the two other models, where part of the fleet is managed in-house and another part by third party), and ship owners' rationales for choosing different ship management models have also been discussed (Klikauer, Morris 2003, Mitroussi 2003, Mitroussi 2004a, Mitroussi 2004b, Panayides, Gray 1999, Panayides, Cullinane 2002, Panayides 2003, Payne, Frow 2005, Sletmo 1986, Sletmo 1989, Panayides, Gray 1997). Cost cutting has been identified as a major ship owner outsourcing motive (Panayides, Gray 1999, Panayides, Cullinane 2002). The ship management literature has shown that third party ship managers can achieve economies of scale due to the large fleets that they manage and have greater bargaining power vis-à-vis crews, shipyards and other suppliers. This ideally translates into lower costs for ship owners, especially lower operating expenses (opex). Outsourcing of ship management also enables ship owners to focus on their core commercial competencies, such as chartering or finance, and thus ideally allows for more efficient resource allocation (Panayides, Gray 1997). Mitroussi (2004a) and, 
Mitroussi (2004b) has also shown how outsourcing of ship management adds flexibility to ship owning organizations, which is advantageous in highly volatile shipping markets. Interestingly, Cariou, Wolff (2011) showed that the decision to outsource ship management is strongly moderated by ship owner characteristics (especially the owner's country of domicile) and vessel type characteristics.

The ship management literature has not specifically addressed the issue of energy efficiency and fuel costs. Largely, this literature originates from the period between the 1990s and the early 2000s, when fuel prices were significantly lower than those recently observed. To our knowledge, the ship management and energy efficiency literatures have not engaged in dialog, and indeed they have partly conflicting perspectives on the potential for cost saving under third party management. On the one hand, a central tenet of the ship management literature is that cost cutting is an important ship owner motive for outsourcing ship management to third parties. On the other hand, a few studies about energy efficiency in shipping argue that energy efficiency and fuel cost reductions are difficult to achieve under third party management, because third party managers and their crews lack incentives to reduce fuel consumptions as long as they do not pay for fuel (Faber et al. 2009, Jafarzadeh, Utne 2014, MaddoxConsulting 2012, Rehmatulla 2011, Crist 2012). This divergence leads to the question of whether or not ship management models have any effects on energy efficiency. In the following, we will bring the two streams of literature together, asking two related research questions:

1. What are the main challenges in regard to energy efficient ship operations?

2. How does the ship owner's choice of ship management model influence energy efficiency in ship operations?

Overall, our study makes an empirical contribution to the hitherto largely separate literatures on energy efficiency and ship management.

We focus on ship operations and crewing only. Ship operations represent the most obvious place for shipping companies to commence their fuel saving efforts, the "low-hanging fruits" so to say. As identified 
by the Marginal Abatement Cost Curves, little or no investments are required to implement operational measures such as optimized voyage planning and execution (see, e.g., Eide et al. (2011b), Buhaug et al. (2009)). Technical management, including timely vessel maintenance, can also influence fuel consumption but goes beyond daily operational decisions. Investments in fuel-saving equipment or vessel retrofits are often required here and therefore technical management and its effects on energy efficiency deserve a study in their own right.

Our paper is structured in the following way: First, we present our methods and data. Second, we identify the various operational fuel saving measures available and assess to what extent they are actually employed. Third, we discuss if and how different ship management models influence energy efficiency in ship operations. We then discuss the management implications of our study for ship owners and engage in discussions with the energy efficiency and ship management literatures. Finally, we conclude and present proposals for further research.

\section{Methods and data}

Our aim is to analyze perceptions and experiences held by decision makers in international shipping companies with regard to energy efficient ship operations and ship management models. Firstly, we are concerned with shipping company managers' and executives' views on the cost effective fuel saving potential in ship operations as well as the challenges they experience in this regard. Secondly, we are concerned with their views on ship management models and their potential effects on energy efficiency in ship operations.

Our study concerns issues, which are commercially sensitive both to ship owners and managers and besides highly complex and context-dependent. We have therefore opted for semi-structured interviews (the interview guide is presented in the Appendix to the paper) to collect data. From the summer of 2012 to the summer of 2014 we performed a total of 56 interviews (one informant was interviewed twice) in 33 
companies and organizations. Since we focus on ship owners' experiences with regard to energy efficiency in ship operations under different ship management models, the majority of our respondents were employed in shipping companies (36 informants were employed in 19 shipping companies).

With the exception of one German container shipping company, our sample includes responses from representatives in Danish shipping companies. Danish shipping companies engage in global shipping on a large scale and they own and operate product, chemical and LPG tankers, bulk carriers, containerships and multipurpose vessels (MPPs). Some of them have in-house ship management (the traditional management model), whereas others rely either fully on an outsourcing management model or adopt a hybrid management model. However, we recognize, as also concluded by Cariou and Wolf (2012), that ship owner nationality is a strongly moderating factor regarding the choice of ship management model, and that comprehensive generalisations therefore should not be made on the basis of our study.

We interviewed top executives and middle managers in shipping companies. On the technical side of the business, the respondents held such positions as head of technical department, technical manager and head of ship performance management. On the commercial side of the business, respondents had positions in top management, chartering, operations and finance. Due to the commercially sensitive nature of the issues discussed, we have promised all respondents confidentiality. However, to clarify the basis of our conclusions, we indicate the positions, and expertise of respondents, when we quote their viewpoints or experiences.

Our interview questions were organized according to main themes in relation to energy efficiency. To construct these themes, we compiled a list of operational fuel saving measures identified from the Ship Energy Efficiency Management Plan (SEEMP) guidelines released by the United Nation's International Maritime Organization (IMO). The "purpose of a Ship Energy Efficiency Management Plan (SEEMP) is to establish a mechanism for a company and/or a ship to improve the energy efficiency of a ship's operation" (IMO 2012), and the IMO guidelines contain a list of relevant operational measures to achieve this. 
Moreover, we have used energy efficiency guidelines by classification societies to identify the main categories for potential fuel saving measures in ship operations (Lloyd's Register 2012, ABS 2013). On this basis, we specifically look at three main operational categories, which will also structure the way in which we present our analysis on fuel saving potential:

1. Voyage execution

2. Onboard power demand

3. Performance monitoring

With the aim to get balanced information from a variety of perspectives we interviewed 20 relevant employees in 15 other companies and organizations, including two ship management companies; shipbrokers; classification societies; naval architecture consultancies; suppliers of automation and fuel saving equipment for ships; a technical research institution; and a nautical school. These respondents all hold technical expertise with regard to fuel saving measures and we have primarily used their answers to critically assess the information regarding fuel saving potential that we obtained in the shipping company interviews.

To analyze the vast amount of qualitative evidence thus collected, we followed the coding procedures of grounded theory (Bryant, Charmaz 2007). Except for five interviews, where we had to rely on concurrent note taking and supplementary notes written immediately after the interview (meeting records), the interviews were tape recorded and transcribed verbatim. The data were coded electronically by using NVivo 10 software for Windows (QSR International Pty, Ltd., Cambridge, MA, USA).

We prepared three broad-brush codes (called nodes in NVivo) derived from our research interest in the relationship between ship management, fuel saving measures, and energy efficiency. These were 1) Tonnage Ownership and Control (TOC); 2) Energy Efficiency Potential (EEP); and 3) Energy Efficiency Fleet Monitoring (EEFM). We then continued by exploring each of the nodes and entering more detailed subcodes in the program (so-called child nodes). We added three additional codes (free nodes) that were not 
directly related to the research question, but which were nevertheless relevant for understanding the context within which ship energy efficiency initiatives are undertaken; namely 4) Sources of Competitive Advantage; 5) Cargo Owners' Future Outlook; and 6) Regulation. Through these steps, we developed a final listing of 58 nodes (see Table 2 for an overview). The nodes were then attached to the respondents' accounts (viewpoints, everyday words, sentences and whole paragraphs in the transcripts and memos) and summarized in coding reports to be used for comparison. We proceeded by examining each of them with the aim of identifying the context in which the respondents' answers were embedded and analyzing the causal connections inferred for each as well as the interconnections between them.

\section{INSERT TABLE 2 ABOUT HERE}

To increase the credibility of our results we pursued respondent validation (i.e., consistently cross checking our findings and interpretations with respondents) in several ways (Bloor 1997). During interviews we often restated and summarized the viewpoints of the respondents and asked them to which extent they would concur with our interpretations. In general, the respondents affirmed the accuracy and completeness of our interpretations. Besides, as we progressed in our data collection and data coding process, we increasingly confronted individual respondents with statements and viewpoints provided in previous interviews with other respondents, and we asked them their opinion on the same issues. In this way we were able to identify different opinions regarding fuel saving potential.

Throughout the period of research we also pursued external validation through the triangulation of sources (Denzin 1978): we shared our interpretations with the broader shipping business community by presenting our preliminary results at conferences that had participation of both researchers and practitioners. At these conferences, many of our interview respondents participated and engaged with us in discussion of our findings. At one of the major conferences (Green Ship Technology 2014, Lillestrøm, Norway) we organized a $1.5 \mathrm{~h}$ panel discussion on energy efficiency and performance monitoring. At the beginning of the panel discussion, we presented the results of this study. Subsequently, each of the six panel members (a nautical 
school teacher/former seafarer, two shipping company performance monitoring experts, a head of operations and bunkers in a shipping company, a technical expert in a ship owner association, and a maritime administration official) commented our findings and thus provided valuable external validation of our results. In addition, we have presented our preliminary results in the maritime business press and trade journals, both in interviews and in own feature articles (Poulsen, 2012a; 2012b; 2013a; 2013b; 2013c, 2014a; 2014b). These communicative measures have allowed our respondents and others in similar positions to critically analyze our results and comment on them.

Our data set has a number of limitations that deserve mentioning. We have only done interviews in two ship management companies and, so, we do not commendably cover the ship managers' perspectives on energy efficiency. We believe that ship management company perceptions of energy efficiency provide an obvious and important area for further research. Our main focus in this paper is on the perceptions of the onshore shipping company decision makers, who decide whether or not to outsource crewing. 16 of our respondents had substantial seafaring experience, but only one person currently works at sea. This means that the seafarers' experiences regarding energy efficiency are also not adequately covered in our analysis. A highly relevant question for further research would be if seafarers' perspectives differ from their shore colleagues with respect to energy efficiency.

\section{Analysis}

In the following sections we first investigate the operational fuel saving measures generally available in vessel management, as derived from the SEEMP guidelines and guidelines published by the classification societies Lloyd's Register and ABS, and consider the major challenges shipping companies experience in this regard. More specifically, we relate our conversations with shipping company representatives to three particularly pertinent categories of measures; namely voyage execution, onboard power demand, and performance monitoring. We then, in section 3.2, examine our data for substantiations regarding energy efficiency gaps in ship operations under different ship management models. 


\subsection{Energy efficiency challenges in ship operations}

\subsubsection{Voyage execution}

Voyage execution influences fuel consumption in various ways, in particular through service speed choice. The power output required for marine propulsion is a function of the speed to the power of three to four (Kristensen 2014, Kristensen 2010, Buhaug et al. 2009), and speed reduction is a well-known and highly effective fuel saving measure, as also confirmed in many of our interviews. Slow steaming became widespread in international shipping during the crisis after 2008 (Cariou 2011). After initial doubts about the technical feasibility of running ships' main engines at loads considerably below the optimum design point, several trails demonstrated the potential of the new practice. Due to the fact that slow steaming ships spend more time en route, the practice reduced two problems for the industry at the same time: Reducing fuel costs and taking out excess capacity in depressed freight markets (Lloyd's List 2008, Lloyd's List 2010, Lloyd's List 2011). As pointed out by a commercial manager in one of the shipping company interviewed for the present study, however, slow steaming is a purely commercial decision based on consideration of the time value of the cargo (cargo-time sensitivity), the supply of ships and the fuel costs at the time of the voyage. In contrast, voyage execution does not concern commercial issues. It relates to speed choices made during each stage of a voyage, after departure and arrival times have been settled onshore in a shipping company or between a shipping company and a charterer.

Charter parties specify vessel service speeds and port arrival times, and operation departments onshore translate this into voyage instructions, which they provide to bridge officers who then use this for operational decisions in executing the voyage. For energy efficient voyage execution, close communication between ship and shore is important regarding all the energy efficiency related issues we discuss below.

Often the respondents in shore-based, commercial shipping company positions experience problems in communication regarding voyage execution. The head of operations and bunkers in a shipping company explained that he had observed many cases of communication problems between ship and shore, where 
the onshore operations department would simply instruct the crew to proceed at "most economical speed", without specifying the information in knots. This is problematic, because seafarers and shore staff may have different views on what is the "most economical speed" in a given situation. What is most economical speed will depend on such decision parameters as the freight market conditions, fuel prices, and cargo values, all of which are information that is not available to the crews.

Using constant speed during the voyage is an effective fuel-saving measure, known as equalized speed over voyage. It means that the ship keeps a stable service speed throughout the voyage and avoids costly, high speeds at the early or last stages of a voyage. Several respondents with seafaring or technical expertise mention imprecise voyage instructions and the common practice of sailing at high speeds at the early stages of a voyage, a practice that developed as a means to buffer against delays at later stages of the voyage. This practice originates from the period of boom freight markets before 2008 , when time was considered the main constraining factor in the charter market. During the good years up to 2008 it was considered commercially very important by ship owners to maximize the number of trips per ship per year, and crews were encouraged by commercial onshore staff to proceed at high speeds. Now several technical and commercial respondents in shore-based positions acknowledge that equalized speed over the voyage is best practice, leading to fuel savings. At the same time, they also indicate that it is not always easy to achieve these savings, either because crews tend to continue old operational practices or because voyage instructions from shore operations departments are imprecise. In ballast voyages, when no charter parties specify service speeds, crews have more freedom with regard to service speed choice and here the communication between ship and shore is seen as crucial for efficient voyage execution.

Reduction of time spent in port, which also allows for speed reduction, has been identified as an additional effective fuel saving measure (e.g. Buhaug et al. (2009), Eide et al. (2009)). Departure time from port depends on the efficiency of unloading and loading, the availability of bunker, and tug and pilot services, and these are often beyond the crew's and the ship manager's direct control. However, a respondent with 
extensive seafaring and performance monitoring experience mentions instances where loading has completed earlier than expected, allowing for an early departure, but where crews nevertheless chose to depart at a later time because no other instructions had come from the onshore operations department. "And if he [the bridge officer] is not good at making the decision [on when to start main engines before departure time], or lacks the experience to decide, then he will typically just say, okay, they have finished loading at $1900 \mathrm{~h}$, but we will only depart at $2100 \mathrm{~h}$, because this is what everybody knows ... then you have lost approximately one and half hours of sailing time." This translates into higher service speed and hence higher fuel consumption. Due to the high pace of short sea operations with frequent port calls, crews can even have personal incentives to sail at high service speeds. A shipping company respondent in charge of operations, and who also possesses considerable seafaring experience of his own, explained: "Sometimes [the captains] burn extra oil in order to arrive in port early and get a sleep." To encourage crews to discontinue old practices several shipping companies in our interview sample have recently started to teach them about the fuel saving potential. The respondents say that they are relatively successful in this regard, but they also agree that good planning of vessel schedules as well as frequent communication between ship and shore are keys to fuel saving through speed reduction.

A vessels' fuel consumption depends on weather, current and wave conditions, and these factors should be taken into account in navigation. Bridge officers can use frequently updated weather forecasts for decision support and change course in order to avoid harsh weather and sea conditions. Several providers of weather routing services exist, and the shipping companies in our sample generally use such services. Even though such systems are quite common, their existence does not guarantee adequate use. Some of the onshore commercial and technical respondents seriously doubt that seafarers actually use the weather routing services fully for decision support. When asked about his experiences with weather routing, the head of operations in a shipping company argued: "The experience is that crew are very inexperienced. And they don't understand the guidelines they receive from shore. You have to go through a lot of pedagogics in order for them to understand what this is all about. This is also new to many ship owners." 
In open sea an autopilot ensures that a vessel remains on course, adjusting the rudder automatically whenever wind, currents or waves bring the ship off course. According to a nautical school teacher, with past bridge officer experiences, some crews use the autopilot extensively, simply because this is easier for them. This has the implication that the ship constantly adjusts its rudders so as to stay on the fixed course specified by the autopilot. However, in the open sea frequent rudder adjustments are unnecessary. Some degrees of freedom in the autopilot instructions will reduce vessel fuel consumption. In some cases the retrofitting of more advanced autopilots are necessary to achieve this, but in many cases fuel savings are possible if existing autopilot systems are used more effectively. The nautical school teacher sees this as a reflection of lack of energy efficiency training, which is a standpoint that is corroborated by shipping company monitoring performance managers in our interview sample who also see an unrealized potential here. Likewise, performance managers often see a potential for fuel saving in ballast optimization. Ships carry ballast water for stability reasons, but often crews are unreasonably cautious and in a habit of carrying too much ballast. Such practices lead to excessive fuel consumption and are often observed by onshore ship performance managers.

Trim, which is the difference between a vessel's forward and aft draft, also affects fuel consumption. Optimal trim differs between vessels and depends on loading conditions, and optimal trim can take both time and experimentation to identify properly. Respondents in technical and commercial positions frequently mention trim-optimization as a promising fuel saving measure that has so far not been fully utilized. In one case, the head of operations and bunkers in a shipping company, which charters vessels under third party management, explains that his company has employed a port captain to trim-optimize vessels, because he feels crews generally lack such competencies. The port captain travels worldwide to the vessels' ports of call, advising crews about vessel loading and trim optimization. The respondent sees this as the best solution for his company to realize at least some of the fuel saving potential, which he says does exist. 


\subsubsection{Onboard power demand}

A ship has numerous energy consuming applications (e.g., inert gas systems, pumps, compressors and other items of auxiliary equipment, and heating, ventilation and air conditioning systems), many of which can be addressed separately. While safety concerns always come first and some energy saving measures are mutually exclusive, respondents in performance monitoring positions agree that there is considerable potential for reduced onboard power demand in many instances. This is in line with the recommendations of the IMO SEEMP guidelines (IMO 2012) and the advice of classification societies (Lloyd's Register 2012, ABS 2013). In order to reduce the onboard power demand, a baseline for each shipboard energy consumer is required. An energy audit, which provides baselines for each piece of equipment and identifies optimum points of operation, will allow shipboard marine engineers and onshore performance managers to identify individual energy consumers, which are not operating efficiently. For instance, generators and auxiliary engines can often operate off the point of peak efficiency, and this can be rectified by using only one unit at peak load instead of both at low loads. Advisers and equipment suppliers see a large fuel saving potential here. The optimization of main and auxiliary engine as well as other equipment is the responsibility of the chief engineer, and technical managers in shipping companies generally agree that there is a saving potential here.

On some vessel types (e.g., LNG and LPG carriers) cargo cooling systems are major energy consumers. One of our respondents, who advises shipping companies on fuel saving, has mentioned an extreme (but apparently not uncommon) example of an empty gas carrier sailing from Europe to South America with the cooling system turned on. It takes a few days to cool down the empty cargo tanks before loading can commence, but on this particular voyage, which lasted several weeks, the system was turned on during the full voyage, causing a considerable waste of energy. Crew had not received any instructions from shore to correct the inefficient practice, possibly because such waste is not immediately evident to seafarers or shore organizations from the energy consumption data in the vessel's performance monitoring systems. While this example is extreme, and the frequency of such is impossible to assess on the basis of interviews, 
it illustrates how important information on energy consumption and ship-shore communication regarding energy efficiency is for energy efficiency.

The technical director in one shipping company explained to us that his company has recently started to assess energy consumption in vessel accommodation (so-called hotel functions), arguing that this consumption is usually neglected because it is typically seen as insignificant. However, in the energy audit process the company has been able to identify and gain non-trivial savings by simply turning off lights and air conditioning whenever possible. The respondent, who has considerable technical expertise, was astonished by the scale of savings achieved by this initiative, which was in the order of $0.5-1 \%$ of total vessel energy consumption. In contrast, many of our other respondents told us that they were not specifically focused on energy consumption in vessel accommodation, which they found inconsiderable in comparison to the power used for propulsion. The fact that respondents diverge on this topic illustrates that the outcome of individual fuel saving initiatives in ship operations cannot be properly anticipated $a$ priori. In many cases real world experiments need to be performed onboard ships, and the actual savings can only be properly assessed subsequently. This can be a time consuming process, according to the performance monitoring experts and naval architect and classification society advisors.

\subsubsection{Performance monitoring}

Overall energy efficiency management has been advised by several studies of land-based energy intensive industries and energy efficiency management requires thorough monitoring of the performance of every energy consumer (Sivill et al. 2013, Bunse et al. 2011, Thollander, Ottosson 2010). The IMO's SEEMP guidelines and in the classification society guidelines for fuel saving, mentioned above, advise shipping and ship management companies to systematically invest in performance monitoring systems and practices. However, in a different study of current performance monitoring practices in international shipping, based on the same set of interview data as analyzed in the present article, we have identified considerable problems related to the collection and analysis of energy consumption data in shipping onboard and ashore 
(Poulsen and Johnson, 2015). In many cases SEEMP is seen as a compliance document and has not led to any significant changes in ship operations. It merely specifies what "the smart ship owner" should already be doing, according to a naval architect consultant.

Extensive submetering and real time data on energy consumption are required for efficient decision support onboard and ashore, but these are largely lacking in international shipping today. This means that the basis for decision making with the aim of fuel saving remains problematic. Improved data on energy consumption, but also data on voyage, hull and maintenance conditions are necessary with the aim to establish a proper baseline for energy saving measures. In such cases, overall energy efficiency management is hindered by lack of information on energy efficiency. Establishing benchmarks and proper time series on energy consumption, with the aim to identify best practice, is a time consuming process. They require years to implement, according to performance monitoring experts and classification society and naval architect consultants.

The well-known problem of marine biofouling can illustrate the problems associated with performance monitoring and lack of valid and reliable information on energy efficiency. Biofouling of hull and propellers occur gradually, in particular in tropical waters and when vessels are idle for extended periods of time. It increases a vessel's resistance through the water and causes considerable increase in fuel consumption, as explained by performance monitoring experts in shipping companies. This problem can be addressed by divers, who clean hull and propellers while the ship is anchored or in port. Although crews cannot perform this task, they still have an important role to play with respect to fouling control because they can regularly observe hull and propeller condition. This information will allow the performance monitoring managers to identify the optimal timing for the hull and propeller cleaning. Respondents agree that the frequency of hull and propeller cleaning has increased in the last couple of years following the rise in fuel prices, so the problem has been reduced relative to the situation before 2008. One of our respondents, who is senior manager in a performance monitoring department, however notes that evidence of bio-fouling are 
sometimes difficult to get from the crews: "... the crew can easily go down and check out the hull of the ship and check if any green stuff sticks to the freeboard, and they go back and give no further thought to the fact that green algae and sea-grass etcetera stick to the hull ... So we say to them, whenever you have the opportunity to photograph the hull of the ship ... please do so. And send the picture to us. We are very interested in seeing how it looks. We get a lot of data from ships, but the quality of the data varies considerably ... they have the information out there, but they just don't give it to us ... Here, much better communication [between ship and shore] is crucial." The fact that photography is used for assessment of hull condition and performance monitoring indicates the poor state of the information basis for energy efficiency initiatives in shipping.

\subsubsection{Challenges for energy efficiency in ship operations}

All the above initiatives and measures are relevant for fuel saving efforts, regardless of the ship management model. Our respondents generally agree that there is still a non-trivial fuel saving potential, even though progress has been made due to implementation of some of the above measures since 2008 . Based on the interviews we identified key challenges regarding energy efficiency in ship operations. These pertain to two key aspects, namely lack of information on energy efficiency and lack of time to provide and diffuse this information.

Fuel-saving initiatives are time consuming activities, often extending over several years. Several of the shipping companies represented in our sample had already commenced their fuel saving efforts around 2008, when fuel prices were high and freight markets plummeted, setting up dedicated performance monitoring departments. They describe their efforts in this respect as long-term processes through which fuel saving goals shall be defined, focus areas identified and prioritized, and saving initiatives implemented, monitored and subsequently evaluated. Based on the results of the experiments, information on best practice can be diffused in the technical organizations ashore and at sea, and new goals can subsequently be set. The performance monitoring experts' descriptions of these processes of continuous improvements 
based on gradually improved information are generally in accord with the fuel saving advices of the IMO and the classification societies (IMO 2012, Lloyd's Register 2012, ABS 2013), and are corroborated in our interviews with the classification societies and naval architects. Respondents from technical organizations ashore emphasized that continuity in relationships among stakeholders, including crews, ship managers and performance monitoring specialists, are key for these processes to be successful. For instance, the identification of optimal trim or optimization of onboard power demand requires crews and shore organizations to collaborate and communicate closely over an extended period of time, in the search for new solutions. Continuous two-way information exchange between ship and shore regarding energy efficiency is crucial is this respect.

During our interview sessions, employees in onshore performance departments often complained about the energy consumption data sets available for energy efficiency efforts. Data of poor quality makes efforts to identify saving potential very difficult, because reliable baselines remain unknown, and proper energy models cannot be created with the aim to analyze shipboard energy consumption. Information also pertains to training. Numerous respondents, either with seafaring or commercial background, note that energy efficiency was never on their curriculum, and they argue that they had to acquire such insights or training later in life. Fuel saving requires training of both seafarers and shore managers.

In summary we would emphasize that energy efficiency in ship operations requires that valid and reliable information on vessel energy consumption is available to all stakeholders, at sea and onshore. It takes several years to identify best practice for ship operations and the diffusion of the information across organizations is key to achieving the goal of energy efficiency. 


\subsection{Effects of ship management model on energy efficiency}

\subsubsection{The challenges for energy efficient ship operations under third party management}

We asked the shipping company respondents open questions about the circumstances under which they consider fuel saving in ship operations would be most easily achieved. While seeing energy efficiency as a general challenge in all ship operations, they agree that traditional, in-house ship management is the model currently best suited for fuel saving. The arguments from shipping companies - regardless of management model - are clear: Under the traditional model there is generally more time for fuel saving initiatives, and information regarding fuel saving potential is more easily provided and shared by decision makers at sea and onshore. In an interview in a shipping company with an outsourcing management model, the head of the technical department refuses to believe "that there are any technical managers, or their crewing agents, that can find a major group of seafarers, who are focused on this [fuel saving]."

In the post-2008 crisis years, many of the shipping companies that rely on traditional or hybrid ship management models have initiated fuel saving training courses for their own chief officers, focusing in particular on voyage execution, power management and performance monitoring. These courses, which are run by performance monitoring experts or external consultants, have provided significant fuel savings, because they diffuse best practice for energy efficient ship operations. However, crews employed by third party managers are not included in these courses, because crew training is the responsibility of the third party manager. After the signing of a ship management contract, the ship owner has little opportunity to engage in crew training. It is worthwhile noting that the paragraphs of the BIMCO SHIPMAN and CREWMAN contracts, which are commonly used as basis for third party ship management contracts, do not specifically address the issue of fuel consumption or energy efficiency training (BIMCO 2009a, BIMCO 2009b).

The sharing of information regarding energy efficiency and best operational practice tends to be minimal when crewing is outsourced to independent ship management companies. Several respondents in shipping company technical departments and performance monitoring departments explain that they do not have 
direct contact to the crews that are employed by third party managers. This obstructs their efforts to identify fuel saving potential and develop a common understanding on energy efficiency. In one of our interviews, the head of operations from a shipping company with a hybrid ship management model explains how conditions for fuel saving differ between vessels with in-house and outsourced ship management. Talking about the fleet managed in-house, he says: “...these are our own vessels and we also have technical management for these ... you can go one step further [with fuel saving initiatives on these vessels]. It is easier when you have crew onboard that works for the principles that you stand for." When asked about crew engagement in fuel saving, another respondent, who works as head of the technical department in a shipping company with an outsourcing ship management model, says: "That's tricky, because our crews are all employed by our third party manager. Therefore, we do not have daily contact with the crews. We don't host crew seminars; we don't make campaigns onboard to the same extent, as you would do if you had a permanent staff. Then you would try to train them all the time, but we risk that a crew will never return to you because they will soon be sailing for another ship owner...." He concludes rhetorically: "So, how much would you want to spend on training such a crew?"

Respondents relying on the outsourced management model argue that low crew retention rates among third party ship managers hamper fuel saving effort. Crews often only work on the same ship for relatively short periods of time, returning to other ships or shipping companies after shore leaves (Sornn-Friese and Hansen, 2012). This means that experiences with regard to fuel saving initiatives, which are often ship specific, are not fully accumulated onboard the ship and within organizations. A global undersupply of competent seafarers causes the low retention rates, in particularly among third party ship managers. One of our respondents in a shipping company with an outsourcing management model explains the main disadvantage of outsourcing, i.e., the lack of time and information, in the following way: "... in case of a high employee turnover with the ship manager ... then there is a risk of losing experience concerning the vessel and what to do in different situations ... For us it is important to gain access to the experience that they [third party ship managers] build up..." 


\subsubsection{The trade-off between outsourcing and energy efficiency}

We have openly asked respondents with vessels under third party management if they consider to insource crewing in order to enhance energy efficiency. Respondents consistently acknowledge that there is a tradeoff between energy efficiency and outsourcing. Under current market and operating conditions (as reflected in, e.g., freight rates, fuel prices, crewing costs, and size of organization), however, none of them consider insourcing. The benefits of outsourcing crewing still outweigh its disadvantages. Our respondents do not expect to see a new trend of back-sourcing ship management, despite the current energy efficiency gap.

When asked whether it would not be easier to implement energy efficiency initiatives with a traditional, inhouse ship management model, a CEO in a medium-sized shipping company agrees and then adds the following: "This is not possible in most cases. It is simply impossible. In some countries it may be possible, but not here [in Denmark] ... it is simply too expensive." In other words, even though outsourcing may increase fuel costs, other cost-reduction benefits of outsourcing exceed the disadvantages. By insourcing, crewing would become too expensive. These companies generally see their own organizations as too small to accommodate crewing and technical departments, believing that they cannot achieve the same economies of scale as third party managers. A shipping company CEO explains the rationales for outsourcing ship management to third party in the following way: "You could say that the optimal situation would be to have your own technical operation. Ideally most shipping companies would prefer this. However, our fleet is simply too small to warrant this." Small and medium-sized shipping companies prefer to focus on their core competencies in chartering, which are of a commercial rather than a technical nature.

Respondents from the shipping company respondents that rely on outsourcing or hybrid management models also confirm the advantages of organizational flexibility that comes with outsourcing. For example, a shipping company CEO with a relatively small fleet argues against in-house crewing for the following 
reason: "Today HR ... can quickly become a dominating issue in large companies. ... It takes considerable time ... it takes time from the management side, and suddenly you find yourself spending $80 \%$ of your time on such soft issues... That may be right, but ... I believe it is better to keep a focus on the business."

Several of the companies for our study employ a hybrid management model, and respondents from these companies argue that in-house ship management is a valuable resource for them, providing them with operational and technical expertise, which companies that rely on the outsourcing model lack. They see this expertise as a necessity for defining, implementing and assessing fuel saving initiatives, doing proper performance monitoring and diffusing energy efficiency information across their organizations. They moreover see it as critical for proper assessment of new vessels designs and marine technology, when new ships are ordered, or second hand vessels are acquired. There is clearly not one ideal model for ship management, but consensus regarding the challenges for energy efficiency in ship operations under third party crew management is evident across our interview sample.

\subsubsection{Achieving energy efficient ship operations under third party management}

Our study has management implications for shipping companies that rely on an outsourcing management model. We have identified several aspects of energy efficiency, which are at least partly within such companies' own control and where further fuel saving initiatives could be initiated without insourcing of crewing.

Timely provision of energy efficiency information is crucial for any initiative to save fuel in ship operations, regardless of the chosen ship management model. We have identified serious problems that are related to vessel performance monitoring, which provides information on energy consumption and should serve as key input for daily operational decisions at sea and onshore. To run ships energy efficiently requires detailed, real time data and extensive sub-metering of the major energy consumers onboard. Ship owners should consider establishing such systems and investing in flow meters and sensor equipment, which measure bunker consumption in real time. While several shipping companies, with the traditional or hybrid 
ship management model, have set up performance monitoring departments and hired specialist to do performance monitoring, shipping companies with the outsourcing model should consider similar initiatives, either in-house or engage with energy efficiency consultants and external advisors.

Moreover, it is important for shipping companies to acknowledge the human dimensions of performance monitoring and energy efficiency. Several technical respondents in shipping companies, classification societies and naval architecture consultancies emphasized that the common engagement of crews and shore staff in performance monitoring is crucial for fuel saving efforts to succeed. Crews play a crucial role in gathering energy consumption data and shore staff has an important role in analyzing data and evaluating fuel saving measures. Respondents in technical positions noted that crews' engagement in energy efficiency tend to depend on the feedbacks they receive from shore staff. When feedback is infrequent or non-existent, as is often the case under third party ship management, energy efficiency awareness among members of the crew tends to suffer. Therefore shipping companies should consider improving mechanisms for the sharing of information on energy efficiency between ship and shore.

Many respondents also acknowledge that crews are already busy, both while at sea and in port, and should not be overloaded with new obligations for collection of energy consumption data. Here auto-logging systems for energy consumption monitoring could be worthwhile considering. On the other hand, many respondents agree that crews should not be totally decoupled from performance monitoring, if autologging systems were to be installed. They believe that this could reduce their engagement in fuel saving initiatives or give them an undesirable feeling of "big brother watching". In other words, striking a balance with regard to performance monitoring obligations is required.

Training of commercial shore staff, who makes operational decisions with impact on vessel fuel consumption, is an important mechanism for diffusion of information on energy efficiency. Notably, the voyage instructions send from onshore commercial operators to the masters at sea could often be improved in terms of precision, because they directly influence speed and fuel consumption. 
Communication between decision-makers, who are in different locations and never meet face-to-face, is challenging. It is important that onshore staff understands how seafarers interpret their voyage instructions and commercial operation departments should enhance precision when formulating voyage instructions (e.g., on optimal trim, equalized speed over voyage). Moreover, shore organizations should ensure that information on changes in voyage instructions, while the ship is en route (e.g., change in port arrival time), is supplied timely to the ships, so that crews immediately can correct speed accordingly.

Acknowledging that fuel saving initiatives take years to asses and benefit from, shipping companies could consider entering into long-term relationships with third party ship managers and strengthen incentives for crew retention. At least one shipping company pays bonuses to crew members from third party managers who return to the same vessel after shore leave. Moreover, shipping companies could consider including further requirements for crew training courses in the management contracts, with the aim to raise energy efficiency awareness among crews from third party managers.

Shipping companies should also consider possibilities of incentivizing fuel saving for crews employed by third party managers. Today vessel energy saving award competitions, where crews on the best performing vessels are recognized, are used by a small group of liner shipping companies in our sample. However, before any such incentive program can be widely implemented, reliable and credible information on energy efficiency and fuel consumption should be made available within and across organizations. Many respondents remain skeptical in this regard, seeing current information problems in performance monitoring as the main restraining factor. As long as information from performance monitoring remains poor, no valid and reliable benchmarks exist and legitimacy of incentive programs among crews will therefore suffer. This is another argument as to why ship owners should start energy efficiency initiatives by improving energy efficiency information from vessel performance monitoring. 


\section{Discussion}

We motivated our study on energy efficiency under different ship management models with a conundrum, which arose from a comparison between the energy efficiency and ship management literatures. On the one hand, the literature focusing on energy efficiency in shipping maintains that energy efficiency and fuel cost reductions are difficult to achieve under third party management, because third party managers and their crews do not pay for fuel (as explained in Section 1.2). On the other hand, in the ship management literature there is general consensus that cost cutting is an important motive for the ship owner to outsource crewing to third parties (as explained in Section 1.2).

Our study has identified a trade-off between energy efficiency in ship operations and outsourcing of crewing. While outsourcing can indeed reduce crewing costs for shipping companies, it may come with a penalty in the form of higher fuel costs. While acknowledging this trade-off, the shipping company managers and executives who resort to the outsourcing management model emphasize that the benefits of outsourcing still outweigh its disadvantages. The ship management literature, as discussed in section 1.2 above, developed largely in the 1990s and early 2000s, at a time when fuel costs were below present levels, and to our knowledge the literature has not addressed the issue of fuel costs specifically. Our study thus contributes to the ship management literature by introducing a new and important aspect of ship costs (fuel costs) and by demonstrating how shipping companies' outsourcing of crewing can influence costs associated with fuel consumption.

We also contribute to the energy efficiency literature by demonstrating why ship management models influence energy efficiency in ship operations. Indeed, third party ship managers and their crews do not pay for fuel but pass these costs on to the ship owner (or the charterer of the vessel, depending on the type of charter the vessel operates under), as previously emphasized in the shipping-oriented energy efficiency literature. Theoretically, this could lead to split incentives, one of the energy efficiency barriers discussed in the introduction to this paper. However, under the outsourced ship management model the problem of 
energy efficiency gaps is caused more fundamentally by the lack of time and information in regards to energy efficiency. Fuel-saving incentives for third party managers and their crews may be weak, but timely provision of information on energy efficiency, including improved performance monitoring and energy efficiency training, could perhaps alleviate the problem.

In our introduction we referred to the various classes of energy efficiency barriers, which had been identified by energy efficiency studies in industry, housing and shipping. The various barriers did not specifically guide our research questions, nor determine our specific questions in the interview guides. Instead we studied the perceptions of the decision makers, mainly in shipping companies, asking them questions regarding their experiences on energy efficiency and ship management. Nevertheless, our study confirms the generally accepted role of imperfect information as a barrier to energy efficiency. Decisionmakers, who work at sea or in shore organizations and influence voyage execution and power management, are limited by the information available to them. Often this information suffers from validity and credibility problems in shipping and this impedes energy efficiency enhancement in ship operations. In many cases there is insufficient time to provide information on energy efficiency to crews under third party management and energy efficiency training is insufficient, thus worsening the problem. Our study thus confirms and extends the imperfect information arguments of the energy efficiency literature to the ship management models. Sorrell et al. (2004) focused on the format in which information on energy efficiency was provided to decision-makers and Johnson, Johansson \& Andersson (2014) identified difficulties measuring energy performance, lack of communication, and lack of knowledge and resources as barriers to energy efficiency in shipping. Our study provides new insights into the question of what kind of energy efficiency information is missing and why information is imperfect under different ship management models. Moreover, the study has highlighted how especially behavioral aspects, including dimensions of bounded rationality and the human dimension, compose barriers to energy efficiency in ship operations. 


\section{Conclusion}

The energy efficiency gap in ship operations is real. There are several cost effective measures to reduce fuel consumption in ship operations, specifically in relation to voyage planning and execution, power management and performance monitoring, but they are rarely fully adopted. Our study has highlighted how especially behavioral aspects, including dimensions of bounded rationality and the human dimension, compose barriers to energy efficiency in ship operations. To enhance energy efficiency in ship operations credible and valid information on energy consumption and fuel saving measures should be made widely available for all stakeholders, at sea and onshore. Identifying, prioritizing, implementing and assessing operational fuel saving measures and diffusing best practice for energy efficient ship operations is a time consuming process, which can take years. Limited availability of information on energy efficiency (including energy efficiency training) and lack of time to experiment with fuel saving currently leads to energy efficiency gaps. The conditions for fuel saving are especially challenging under the outsourcing ship management model, where lack of information on energy efficiency, lack of energy efficiency training and lack of time for fuel saving experiments is particularly pronounced.

Despite the energy efficiency challenges on vessels under third party management, there is no indication in our sample that insourcing of ship management will occur to any great extent. In other words, the unrealized, cost effective fuel saving potential has to be generally realized within the outsourcing management model. Our study identifies several initiatives that ship owners can launch in order to enhance energy efficiency under such circumstances. It is crucial that ship owners improve information on energy efficiency and takes sufficient time to diffuse it broadly across organizations. Here, energy consumption information, based on reliable and credible data from vessel performance monitoring systems, and energy efficiency training is crucial. Ship owners can also incentivize crew fuel saving training and crew retention in third party ship management contracts, while building long-term relations with ship managers to sustain long-lasting fuel-saving initiatives. 
We have focused on ship owners' perceptions on energy efficiency and third party management. Further studies into the third parties' perspectives could potentially provide valuable insights into the occurrence of energy efficiency gaps in shipping. Indeed, Jafarzadeh, Utne (2014) pointed towards the need to study the viewpoints of more stakeholders regarding energy efficiency in shipping, since different stakeholders may encounter dissimilar barriers. The relevant question to ask is if ship managers share the perspectives of their customers in regard to energy efficiency. Moreover, our analysis has focused on operational measures, which require little or no investments in new equipment. However, energy efficiency under third party technical management (including vessel maintenance) could also be an interesting area for further studies. As a technical shipping company director, with a background as naval architect, explains: "We do see examples of vessels, which we have managed technically. Then we sell the vessel and charter it back. Then the ship is under external technical management [including crewing], and suddenly we see how fuel consumption increases ... This gives food for thought." Seafarers' views on energy efficiency also deserve a study in their own right, in order to identify challenges in the diffusion of energy efficiency information.

Our research represents a snapshot of the situation in international shipping between 2012 and mid-2014, and several respondents do indicate that conditions for ship management and energy efficiency have been changing at that time. However, after we completed our interviews two important changes occurred in the marine fuel markets: One that may reduce incentives for fuel saving and one that may strengthen such incentives. From the summer of 2014 to January 2015, oil prices decreased from approximately USD 100 to 50 per barrel (Brent oil), and fuel costs' share of voyage costs decreased accordingly (Lloyd's List 2014a). However, on January 1, 2015, Sulfur Emission Control Areas (SECAs) in the North and Baltic Sea and North American waters, agreed upon by the IMO, entered into force. This legislation requires vessels to operate on fuel with a maximum of $0.1 \%$ sulfur content within these areas (or clean exhaust gas or shift to other cleaner fuel types such as LNG). Marine fuel with $0.1 \%$ sulfur content is significantly more expensive than traditional marine fuel with $2.5 \%$ sulfur content, allowed for ships operating in non-SECAs. Moreover a 
global cap on sulfur content in marine fuel of $1 \%$ in expected in 2020 or 2025, which could lead to further increases in marine fuel prices (IMO 2015, Lloyd's List 2014b).

Further research should look into these changes to identify the actual effects of the various fuel saving initiatives, taking into consideration the changes in oil prices and the entry into force of new regulation of ship emissions. Some fuel saving initiatives may be more successful than others and research into these questions is important. Such research can contribute to the realization of the full potential for fuel saving in international shipping.

\section{Acknowledgements}

We would like to express our gratitude to the Danish Maritime Fund for generously funding our research. A special thanks goes to the two anonymous reviewers who provided valuable comments that forced us to restructure and sharpen our argument. We would also like to thank Hannes Johnson (Chalmers University of Technology) for very helpful comments to an earlier version of the paper. Finally, we are grateful for the valuable inputs by respondents and the feedback provided by them and others at various ship management and other industry specific conferences and workshops.

\section{References}

ABS 2013, Ship Energy Efficiency Measures: Status and Guidance, ABS, Houston, Texas, USA.

Acciaro, M., Hoffmann, P.N. \& Eide, M.S. 2013, "The energy efficiency gap in maritime transport", Journal of Shipping and Ocean Engineering, vol. 3, pp. 1-10.

Agnolucci, P., Smith, T. \& Rehmatulla, N. 2014, "Energy efficiency and time charter rates: Energy efficiency savings recovered by ship owners in the Panamax market", Transportation Research Part A: Policy and Practice, vol. 66, pp. 173-184.

Allcott, H. \& Greenstone, M. 2012, Is there an energy efficiency gap?, National Bureau of Economic Research, Cambridge, MA, USA.

BIMCO 2009a, CREWMAN A (COST PLUS FEE) 2009 - Explanatory Notes, BIMCO, Bagsvaerd, Denmark. BIMCO 2009b, SHIPMAN 2009 - Explanatory Notes, BIMCO, Bagsvaerd, Denmark. 
BIMCO 2009c, August 8-last update, What is 3rd party management? [Homepage of BIMCO], [Online]. Available:

https://www.bimco.org/en/Education/Seascapes/Questions of shipping/2009 0109 What is 3rd party ship management.aspx [2015, July 3].

Bjuggren, P. \& Palmberg, J. 2009, "A contractual perspective of the firm with an application to the maritime industry" in The Modern Firm, Corporate Governance and Investment: New Perspectives on the Modern Corporation, eds. P. Bjurggren \& D.C. Mueller, Edward Elgar, Cheltenham, UK, pp. 63-81.

Bloor, M. 1997, "Techniques of validation in qualitative research: a critical commentary" in Context \& Method in Qualitative Research, eds. G. Miller \& R. Dingwall, Sage, London, UK, pp. 37-50.

Bryant, A. \& Charmaz, K. 2007, The Sage handbook of grounded theory, Sage, London, UK.

Buhaug, $\varnothing$, Corbett, J., Endresen, $\varnothing$, Eyring, V., Faber, J., Hanayama, S., Lee, D., Lee, D., Lindstad, H. \& Markowska, A. 2009, Second IMO GHG study 2009, International Maritime Organization, London, UK.

Bunse, K., Vodicka, M., Schönsleben, P., Brülhart, M. \& Ernst, F.O. 2011, "Integrating energy efficiency performance in production management-gap analysis between industrial needs and scientific literature", Journal of Cleaner Production, vol. 19, no. 6, pp. 667-679.

Cariou, P. 2011, "Is slow steaming a sustainable means of reducing CO 2 emissions from container shipping?", Transportation Research Part D: Transport and Environment, vol. 16, no. 3, pp. 260-264.

Cariou, P. \& Wolff, F. 2011, "Ship-owners' decisions to outsource vessel management", Transport Reviews, vol. 31, no. 6, pp. 709-724.

Crist, P. 2012, "Mitigating greenhouse gas emissions from shipping: Potential, cost and strategies" in Maritime Transport and the Climate Change Challenge, eds. R. Asariotis \& H. Benamara, Earthscan, New York, NY, USA, pp. 165-205.

Denzin, N.K. 1978, The research act: A theoretical introduction to sociological methods, Mc-Graw Hill, New York, NY, USA.

Dickie, J.W., 2014, Reeds $21^{\text {st }}$ century ship management, Bloomsbury Publishing PIc., London.

Eide, M.S., Endresen, $\varnothing$, Skjong, R., Longva, T. \& Alvik, S. 2009, "Cost-effectiveness assessment of CO2 reducing measures in shipping", Maritime Policy \& Management, vol. 36, no. 4, pp. 367-384.

Eide, M.S., Longva, T., Hoffmann, P., Endresen, $\varnothing$ \& Dalsøren, S.B. 2011, "Future cost scenarios for reduction of ship CO2 emissions", Maritime Policy \& Management, vol. 38, no. 1, pp. 11-37.

Faber, J., Behrends, B. \& Nelissen, D. 2011, Analysis of GHG Marginal Abatement Cost Curves, CE Delft, Delft., Netherlands.

Faber, J., Wang, H., Nelissen, D., Russel, B. \& St Amand, D. 2011, Marginal Abatement Costs and Cost Effectiveness of Energy-Efficiency Measures, International Maritime Organization, London, UK. 
Faber, J., Eyring, V., Selstad, E., Kågeson, P., Lee, D., Buhaug, Ø, Roche, P., Graichen, J. \& Schwarz, W. 2009, Technical support for European action to reducing Greenhouse Gas Emissions from international maritime transport, CE Delft, Delft, Netherlands.

Fleiter, T., Worrell, E. \& Eichhammer, W. 2011, "Barriers to energy efficiency in industrial bottom-up energy demand models-a review", Renewable and Sustainable Energy Reviews, vol. 15, no. 6, pp. 3099-3111.

Howarth, R.B. \& Andersson, B. 1993, "Market barriers to energy efficiency", Energy Economics, vol. 15, no. 4, pp. 262-272.

IMO 2015, Special areas under MARPOL [Homepage of International Maritime Organization], [Online]. Available:

http://www.imo.org/OurWork/Environment/PollutionPrevention/SpecialAreasUnderMARPOL/Pages/Defau It.aspx [2015, January 20].

IMO 2012, Resolution MEPC.63/23, 2012 Guidelines for the Development of a Ship Energy Efficiency Management Plan (SEEMP), International Maritime Organization, London, UK.

IPCC 2011, Third assessment report: Climate Change 2001, Intergovernmental Panel on Climate Change, Geneva, Switzerland.

Jafarzadeh, S. \& Utne, I.B. 2014, "A framework to bridge the energy efficiency gap in shipping", Energy, vol. 69, pp. 603-612.

Jaffe, A.B. \& Stavins, R.N. 1994, "The energy-efficiency gap: What does it mean?", Energy Policy, vol. 22, no. 10, pp. 804-810.

Johnson, H. 2013, Towards understanding energy efficiency in shipping, Chalmers University of Technology. Johnson, H. \& Andersson, K. 2014, "Barriers to energy efficiency in shipping", WMU Journal of Maritime Affairs, , pp. 1-18.

Johnson, H., Johansson, M. \& Andersson, K. 2014, "Barriers to improving energy efficiency in short sea shipping: an action research case study", Journal of Cleaner Production, vol. 66, pp. 317-327.

Johnson, H., Johansson, M., Andersson, K. \& Södahl, B. 2013, "Will the ship energy efficiency management plan reduce $\mathrm{CO} 2$ emissions? A comparison with ISO 50001 and the ISM code", Maritime Policy \& Management, vol. 40, no. 2, pp. 177-190.

Klikauer, T. \& Morris, R. 2003, "Human resources in the German maritime industries:'back-sourcing'and ship management", International Journal of Human Resource Management, vol. 14, no. 4, pp. 544-558.

Kristensen, H.O.H. 2014, "Experience with Energy Efficiency Operational Indicators (EEOI) Seen in the Light of MRV (Monitoring, Recording and Verification)", The 36th Propulsion \& Emissions Conference 2014Hamburg, Germany.

Kristensen, H.O.H. 2010, "Model for Environmental Assessment of Container Ship Transport", SNAMEWashington, DC, USA. 
Lloyd's List 2014a, Shipping's fuel bill plummets as oil price falls, October 15 edn.

Lloyd's List 2014b, A tidal wave of regulation for 2015, December 23 edn.

Lloyd's List 2013a, Bunker round-up: Rollercoaster ride, March 1 edn.

Lloyd's List 2013b, Fuel efficiency is shipping's top concern, March 15 edn, Lloyd's List.

Lloyd's List 2012, Bunker prices dip, June 1 edn.

Lloyd's List 2011, Slow-steaming advantages remain', July 28 edn.

Lloyd's List 2010, TSA lines given go-ahead to discuss slow steaming, February 22 edn.

Lloyd's List 2008, The slower you steam, the faster your wear and tear, September 19 edn.

Lloyd's Register 2012, Ship Energy Efficiency Management Plan (SEEMP): SEEMP template for owners and operators, Lloyd's Register, London.

MaddoxConsulting 2012, Analysis of market barriers to cost effective GHG emission reductions in the maritime sector, European Commission, Brussels, Belgium.

Mitroussi, K. 2004a, "The role of organisational characteristics of ship owning firms in the use of third party ship management", Marine Policy, vol. 28, no. 4, pp. 325-333.

Mitroussi, K. 2004b, "The ship owners' stance on third party ship management: an empirical study", Maritime Policy \& Management, vol. 31, no. 1, pp. 31-45.

Mitroussi, K. 2003, "Third party ship management: the case of separation of ownership and management in the shipping context", Maritime Policy \& Management, vol. 30, no. 1, pp. 77-90.

OECD/IEA 2007, Mind the gap: quantifying principal-agent problems in energy efficiency, OECD/International Energy Agency (IEA), Paris.

Panayides, P.M. 2003, "Competitive strategies and organizational performance in ship management", Maritime Policy \& Management, vol. 30, no. 2, pp. 123-140.

Panayides, P.M. \& Cullinane, K.P. 2002, "The vertical disintegration of ship management: choice criteria for third party selection and evaluation", Maritime Policy \& Management, vol. 29, no. 1, pp. 45-64.

Panayides, P.M. \& Gray, R. 1999, "An empirical assessment of relational competitive advantage in professional ship management", Maritime Policy \& Management, vol. 26, no. 2, pp. 111-125.

Panayides, P.M. \& Gray, R. 1997, "Marketing the professional ship management service", Maritime Policy and Management, vol. 24, no. 3, pp. 233-244.

Payne, A. \& Frow, P. 2005, "A strategic framework for customer relationship management", Journal of Marketing, vol. 69, no. 4, pp. 167-176.

Poulsen, R. T. (2012a). Redere med grønne fingre. Søfart, 38, 9. 
Poulsen, R. T. (2012b). Fokus på klimaudfordringen for søfarten. Søfart, 12, 13.

Poulsen, R. T. (2013a). Dagens design-dilemmaer. Søfart, 48, 11.

Poulsen, R. T. (2013b). En ny definition af kvalitetssøfart. Søfart, 38, 10.

Poulsen, R. T. (2013c). Rederiernes nye konkurrenceparameter. Søfart, 17, 7.

Poulsen, R. T. (2014a). Den lange vej til effektiv skibsdrift. Søfart, 18, 12-13.

Poulsen, R. T. (2014b). Den nye søfartspolitik e og dens konkurrencemæssige konsekvenser. Søfart, 17, 11.

Poulsen, R. T., \& Johnson, H. (2015). The logic of business vs. the logic of energy management practice: understanding the choices and effects of energy consumption monitoring systems in shipping companies. Journal of Cleaner Production.

Rehmatulla, N. 2011, Applying systems thinking approach for qualitative analysis of GHG emissions regulations in shipping, University College London, London, UK.

Rehmatulla, N. \& Smith, T. 2013, "Implementation Barriers to Low Carbon Shipping", Low Carbon Shipping ConferenceLondon, UK, 2013.

Rohdin, P., Thollander, P. \& Solding, P. 2007, "Barriers to and drivers for energy efficiency in the Swedish foundry industry", Energy Policy, vol. 35, no. 1, pp. 672-677.

Shinohara, M. 2005, "Quality shipping and incentive schemes: from the perspective of the institutional economics", Maritime Economics \& Logistics, vol. 7, no. 3, pp. 281-295.

Sivill, L., Manninen, J., Hippinen, I. \& Ahtila, P. 2013, "Success factors of energy management in energyintensive industries: Development priority of energy performance measurement", International Journal of Energy Research, vol. 37, no. 8, pp. 936-951.

Simon, H. A. (1957). Models of man: Social and rational. New York: John Wiley and Sons, Inc.

Sletmo, G.K. 1989, "Shipping's fourth wave: ship management and Vernon's trade cycles", Maritime Policy and Management, vol. 16, no. 4, pp. 293-303.

Sletmo, G.K. 1986, "The transformation of shipping and the role of ship management", Research for Tomorrow's Transport Requirements. Proceedings of the Fourth World Conference on Transport Research.

Sornn-Friese, H. \& Hansen, C. Ф 2012, Landlubbers and Seadogs: The Case of Labour Mobility in the Danish Maritime Sector in a Time of Accelerating Globalisation, Copenhagen Business School Press, Copenhagen, Denmark.

Sorrell, S., O'Malley, E., Schleich, J. \& Scott, S. 2004, The economics of energy efficiency: barriers to costeffective investment, Edward Elgar Publishing.

Sorrell, S., Mallett, A. \& Nye, S. 2011, Barriers to industrial energy efficiency: A literature review, United Nations Industrial Development Organization (UNIDO). 
Sorrell, S., Schleich, J., Scott, S., O'malley, E., Trace, F., Boede, E., Ostertag, K. \& Radgen, P. 2000, Reducing barriers to energy efficiency in public and private organizations, SPRU.

Thollander, P. \& Ottosson, M. 2010, "Energy management practices in Swedish energy-intensive industries", Journal of Cleaner Production, vol. 18, no. 12, pp. 1125-1133.

Thollander, P. \& Palm, J. 2012, Improving energy efficiency in industrial energy systems: An interdisciplinary perspective on barriers, energy audits, energy management, policies, and programs, Springer, Heidelberg, Germany.

Trianni, A. \& Cagno, E. 2012, "Dealing with barriers to energy efficiency and SMEs: some empirical evidences", Energy, vol. 37, no. 1, pp. 494-504.

Velthuijsen, J.W. 1993, "Incentives for investment in energy efficiency: an econometric evaluation and policy implications", Environmental and resource economics, vol. 3, no. 2, pp. 153-169.

Vernon, D. \& Meier, A. 2012, "Identification and quantification of principal-agent problems affecting energy efficiency investments and use decisions in the trucking industry", Energy Policy, vol. 49, pp. 266273.

\section{Tables}

Table 1: A Taxonomy of Barriers to Energy Efficiency

\begin{tabular}{|c|c|c|}
\hline Perspective & Sub-division & Barrier \\
\hline \multirow{8}{*}{ Economic } & \multirow[t]{4}{*}{ Rational behavior } & Heterogeneity \\
\hline & & Hidden costs \\
\hline & & Risk \\
\hline & & Access to capital \\
\hline & \multirow[t]{4}{*}{ Market or organizational failure } & Imperfect information \\
\hline & & Adverse selection \\
\hline & & Split incentives \\
\hline & & Principal-agent relationships \\
\hline \multirow[t]{5}{*}{ Behavioral } & Bounded rationality & Bounded rationality \\
\hline & \multirow{4}{*}{ The human dimension } & Form of information \\
\hline & & Credibility and trust \\
\hline & & Inertia \\
\hline & & Values \\
\hline \multirow{2}{*}{$\begin{array}{l}\text { Organization } \\
\text { theory }\end{array}$} & & Power \\
\hline & & Culture \\
\hline
\end{tabular}

Source: Adapted from Sorrell et al. (2000).

\section{Table 2: Final List of NVivo Nodes}

\begin{tabular}{|l|l|l|}
\hline & NVivo node & Node description \\
\hline 1 & $(1)$ & Sources of competitive advantage \\
\hline 2 & $(2)$ & Cargo owners' future outlook \\
\hline
\end{tabular}




\begin{tabular}{|c|c|c|}
\hline 3 & (3) & Regulation \\
\hline 4 & (4) & TOC (Tonnage Ownership and Control) \\
\hline 5 & $(4,1)$ & TOC/ship management \\
\hline 6 & $(4,1,1)$ & TOC/ship management/traditional \\
\hline 7 & $(4,1,2)$ & TOC/ship management/outsourcing \\
\hline 8 & $(4,1,3)$ & TOC/ship management/hybrid \\
\hline 9 & $(4,2)$ & TOC/fuel expenses \\
\hline 10 & $(4,3)$ & TOC/tonnage strategy \\
\hline 11 & $(4,3,1)$ & TOC/tonnage strategy/asset light \\
\hline 12 & $(4,3,2)$ & TOC/tonnage strategy/asset play \\
\hline 13 & $(4,3,3)$ & TOC/tonnage strategy/geographical coverage \\
\hline 14 & $(4,3,4)$ & TOC/tonnage strategy/chartering \\
\hline 15 & $(4,3,5)$ & TOC/tonnage strategy/segments \\
\hline 16 & $(4,3,6)$ & TOC/tonnage strategy/time horizon \\
\hline 17 & (5) & EEP (Energy Efficiency Potential) \\
\hline 18 & $(5,1)$ & EEP/operations \\
\hline 19 & $(5,1,1)$ & EEP/operations/awareness \\
\hline 20 & $(5,1,1,1)$ & EEP/operations/awareness/experience \\
\hline 21 & $(5,1,1,2)$ & EEP/operations/awareness/depth \\
\hline 22 & $(5,1,1,3)$ & EEP/operations/awareness/formation \\
\hline 23 & $(5,1,1,3,1)$ & EEP/operations/awareness/formation/didactics \\
\hline 24 & $(5,1,1,3,2)$ & EEP/operations/awareness/formation/counseling \\
\hline 25 & $(5,1,2)$ & EEP/operations/education \\
\hline 26 & $(5,1,2,1)$ & EEP/operations/education/use of port captains \\
\hline 27 & $(5,1,2,2)$ & EEP/operations/education/continuous training \\
\hline 28 & $(5,1,2,3)$ & EEP/operations/education/influence of nationality \\
\hline 29 & $(5,1,3)$ & EEP/operations/slow steaming \\
\hline 30 & $(5,1,3,1)$ & EEP/operations/slow steaming/experience \\
\hline 31 & $(5,1,4)$ & EEP/operations/trim \\
\hline 32 & $(5,1,5)$ & EEP/operations/virtual arrival \\
\hline 33 & $(5,1,5,1)$ & EEP/operations/virtual arrival/dispersion \\
\hline 34 & $(5,1,2)$ & EEP/operations/virtual arrival/potential \\
\hline 35 & $(5,2)$ & EEP/eco design new-buildings \\
\hline 36 & $(5,2,1)$ & EEP/eco design new-buildings/commercial expectations \\
\hline 37 & $(5,2,2)$ & EEP/eco design new-buildings/actual use \\
\hline 38 & $(5,3)$ & EEP/retrofit \\
\hline 39 & $(5,3,1)$ & EEP/retrofit/acceptable pay-back time \\
\hline 40 & $(5,3,2)$ & EEP/retrofit/experience \\
\hline 41 & $(5,3,3)$ & EEP/retrofit/quality of existing fleet \\
\hline 42 & (6) & EEFM (Energy Efficiency Fleet Monitoring) \\
\hline 43 & $(6,1)$ & EEFM/purpose \\
\hline 44 & $(6,1,1)$ & EEFM/purpose/bonus schemes \\
\hline 45 & $(6,1,2)$ & EEFM/purpose/speed consumption curves \\
\hline 46 & $(6,2)$ & EEFM/monitoring data \\
\hline 47 & $(6,2,1)$ & EEFM/monitoring data/internal use \\
\hline 48 & $(6,2,2)$ & EEFM/monitoring data/quality \\
\hline 49 & $(6,2,3)$ & EEFM/monitoring data/analysis \\
\hline 50 & $(6,2,4)$ & EEFM/monitoring data/views on data publication \\
\hline 51 & $(6,3)$ & EEFM/SEEMP \\
\hline 52 & $(6,3,1)$ & EEFM/SEEMP/who formulated the template \\
\hline 53 & $(6,3,2)$ & EEFM/SEEMP/purpose \\
\hline 54 & $(6,3,3)$ & EEFM/SEEMP/use \\
\hline 55 & $(6,3,4)$ & EEFM/SEEMP/effect \\
\hline 56 & $(6,4)$ & EEFM/auto logging \\
\hline
\end{tabular}




\begin{tabular}{|l|l|l|}
\hline 57 & $(6,5)$ & EEFM/weather routing \\
\hline 58 & $(6,6)$ & EEFM/trust between ship and shore \\
\hline
\end{tabular}

\section{Appendix 1: An example of an interview guide for an energy consumption monitoring expert and an executive in a tanker shipping company Business practices}

- Could you please explain briefly the main activities of your company?

- Do you have long-term relations with cargo-owners or charterers?

- What expectations do cargo-owners (oil majors) have for your services?

- Do you charter vessels in or out?

- What types of charters to do you engage in?

$\circ$ And with what durations?

- If you charter in vessels, how do you select them?

- Do you observe differences between chartered and owned vessels?

If yes, which and why?

- How do you crew your vessels?

- Do you employ your own crews onboard the vessels or use third part ship managers?

○ Why?

- What are the advantages and disadvantages of using in-house crewing and third party ship management, respectively?

- How frequently do crews change?

- What are the key sources of corporate competitiveness in tanker shipping?

- Who pays the fuel costs?

\section{Potential for fuel saving}

- In your annual report you provide information on fuel saving initiatives in your company in the last couple of years:

- What are your experiences in this regard?

- How did you achieve the savings?

- What were the major challenges in this regard?

- Have the initiatives surprised you in any way?

- Have you now realized the full potential for cost effective fuel saving measures?

$\circ$ If no, why not?

- And where does a potential exist?

- Are you sure such initiatives are cost effective?

- What is the fuel saving potential with regard to operational measures? Speed reduction, voyage execution, power management, performance monitoring?

\section{How and why energy consumption monitoring is performed}

- How do you monitor fuel consumption onboard your fleet? 
- How frequently do you monitor vessel fuel consumption?

- What are the procedures you employ for monitoring of vessel fuel consumption?

- For how long have you done so?

- What is the level of detail in your fuel consumption monitoring? What is monitored?

- How do you analyze the fuel consumption data that you gather?

- What methods do you employ to analyze data?

- What do you use energy consumption monitoring data for? Why?

$\circ$ Did you ever consider implementing fuel saving competitions between your vessels? Why/why not?

- Do you provide crews with feedback based on the energy consumption monitoring data analysis? Why/why not?

O In case you provide feedback, how do crews react to this?

- Do you observe any difference in terms of energy efficiency performance within your fleet?

$\circ$ If yes, how big are the differences?

- Are they also observable between sister ships?

If yes, which ships are best in class and which are the worst performers?

- Why?

- How do you address differences in performance between vessels?

- Do you have a SEEMP?

If yes, who formulated it?

- Why did you establish it?

- Do your ships have individual SEEMPs or are SEEMPs identical for all vessels?

- What effects (if any) do the IMO SEEMP requirements have on your business?

- How do you perform in terms of fuel saving and energy efficiency when compared to competing shipping companies?

○ How do you know?

$\circ$ In the case of a performance difference, what is the reason for this?

\section{Validity and reliability of energy consumption monitoring data and best practice}

- What is the quality of the energy consumption monitoring data you receive from ships?

$\circ$ Other interviewees have explained that they observe significant noise in energy consumption monitoring data: Is that also the case for you?

- Does energy consumption monitoring data quality vary? If yes, when and why?

$\circ$ How do you assess the quality of noon reporting systems and auto-logging systems?

- Which of the systems do you prefer? Why?

$\circ$ Do you have flow meters installed onboard your vessels?

- What is best practice energy consumption monitoring for you?

- Interviewees in other companies have explained how they experiment with various fuel saving measures, such as the ones mentioned below. Would they be relevant for your?

- Continuous energy consumption monitoring and auto-logging systems?

$\circ$ Vessel fuel saving competitions?

- Energy efficiency training courses for crews?

If no, why not? 
- Which roles do crews and shore organizations have in regard to fuel saving?

$\circ$ How do you engage crews and shore employees in fuel saving efforts?

- Do you train employees on shore and at sea?

- What are the ideal conditions for fuel saving?

- Does outsourcing of ship management influence fuel consumption? 